\title{
PERAN AKTIF MAHASISWA DAN MASYARAKAT DALAM MENGHADAPI FENOMENA PANDEMI COVID-19 DI DESA TUWUNG KECAMATAN KAHAYAN TENGAH
}

\author{
Rinto Alexandro ${ }^{1 *}$, Suita Manurung ${ }^{2}$, Puteri Neriasi ${ }^{3}$, Oliver Situmorang ${ }^{4}$, Ahmad \\ Hidayat $^{5}$,Tantan Gunawan ${ }^{6}$, Astri Susana ${ }^{7}$, Regina Halent ${ }^{8}$, Nurul Hazmi ${ }^{9}$, Seri Wahyuni ${ }^{10}$, \\ Dechrist Event $^{11}$, Zakia Aprilianti ${ }^{12}$, Supri ${ }^{13}$, Anre Tampubolon ${ }^{14}$, Nia Damanik ${ }^{15}$, Gari \\ Purwanto $^{16}$, Hernawati ${ }^{17}$ \\ 1,2,3,4,5,6,7,8,9,10,11,12,13,14,15,16,17 Universitas Palangka Raya \\ *E-mail: rinto.alexandro@fkip.upr.ac.id
}

\begin{abstract}
ABSTRAK
Tahun 2020 ini umat manusia diseluruh penjuru dunia digoncang dengan adanya pandemi Virus Corona (Covid19) yang sangat mempengaruhi kehidupan masyarakat dan menimbulkan banyak kepanikan. Ratusan bahkan ribuan manusia terinfeksi dan sudah banyak yang meninggal dunia akibat Virus Covid-19 ini. Karena Virus Corona (Covid-19) ini juga membuat masyarakat desa Tuwung, Kecematan Kahayan Tengah, Kabupaten Pulang Pisau tersebut terbatas dalam melakukan rutinitas sehari-hari seperti ibadah, sekolah, ajar mengajar, bahkan kegiatan kegemaran seperti bermain bola voli dan lainnya. Permasalahan lainnya yang terjadi adalah sebagian masyarakat desa Tuwung juga kurang disiplin dalam melakukan protokol kesehatan seperti berkerumun dalam banyak orang, tidak memakai masker pelindung, masih berjabat tangan, dan lainnya. Dalam hal ini Mahasiswa Universitas Palangka Raya tidak tinggal diam, mulai dari memberikan banyak himbauanhimbauan, edukasi dan bantuan kepada masyarakat dalam mengatasi wabah Covid-19 ini masyarakat desa Tuwung tetap terjaga dan aman melalui kegiatan KKN-T Periode II Universitas Palangka Raya. Pemerintah Indonesia menerapkan sistem dirumah aja yakni masyarakat Indonesia diharuskan untuk diam dan bekerja dirumah masing-masing. Dan dengan adanya aturan ini membuat Mahasiswa KKN-T Periode II Universitas Palangka Raya melakukan kegiatan yang menerapkan sistem Kerja dari Rumah dan tetap mengikuti protokol kesehatan yang berlaku. Tujuan kegiatan ini adalah memberikan contoh dan pengertian terhadap masyarakat desa Tuwung agar tetap mematuhi peraturan yang berlaku di negara Indonesia. Sehingga melalui kegiatan ini dapat membantu pemerintah maupun tenaga medis untuk memutuskan rantai penyebaran Virus Corona (Covid19) di Negara Indonesia. Dan dengan kegiatan ini juga semakin menyadarkan masyarakat tentang pentingnya menerapkan protokol kesehatan baik di zona merah maupun di zona hijau.
\end{abstract}

Kata Kunci : Desa Tuwung, Covid-19, Mahasiswa KKN-T

\section{ACTIVE ROLE OF STUDENTS AND COMMUNITY IN FACING THE PANDEMIC PHENOMENON OF COVID-19 IN TUWUNG VILLAGE KECAMATAN KAHAYAN TENGAH}

\begin{abstract}
In 2020, mankind throughout the world will be shaken by the Corona Virus (Covid-19) pandemic which has greatly affected people's lives and caused a lot of panic. Hundreds or even thousands of humans have been infected and many have died due to the Covid-19 Virus. Because the Corona Virus (Covid-19) also makes the people of Tuwung village, Kahayan Tengah district, Pulang Pisau Regency, they are limited in carrying out daily routines such as worship, school, teaching, even hobby activities such as playing volleyball and others. Another problem that occurs is that some of the people of Tuwung village also lack discipline in carrying out health protocols such as crowding in many people, not wearing protective masks, still shaking hands, and others. In this case, Palangka Raya University students do not remain silent, starting from providing many appeals, education and assistance to the community in overcoming the Covid-19 outbreak, the people of Tuwung village are maintained and safe through the KKN-T Period II activities of Palangka Raya University. The Indonesian government implements a home system where Indonesians are required to be quiet and work in their own homes. And with this rule, the KKN-T Period II Students of Palangka Raya University carry out activities that apply the Work from Home system and still follow the applicable health protocols. The purpose of this activity
\end{abstract}


is to provide an example and understanding for the Tuwung village community in order to comply with the applicable regulations in the country of Indonesia. So that through this activity it can help the government and medical personnel to break the chain of spreading the Corona Virus (Covid-19) in Indonesia. And with this activity it will also make the public more aware of the importance of implementing health protocols both in the red zone and in the green zone.

Keywords: Tuwung Village, Covid-19, Student KKN-T

\section{PENDAHULUAN}

Virus corona adalah bagian dari keluarga virus yang menyebabkan penyakit pada hewan ataupun manusia . Di Indonesia masih melawan virus Corona hingga saat ini begitu juga dengan Negaranegara lainya. Pelaksanaan Program Kuliah Kerja Nyata Tematik Mahasiswa Universitas Palangka Raya Periode II Tahun 2020, karena adanya masa pandemik Covid-19 Tim membuat satu model KKN di Masa Pandemi Covid-19 dengan Tema salah satunya yaitu Peningkatan Keterlibatan Masyarakat Dalam Upaya Pencegahan Penyebarann covid-19. Sebagai perguruan tinggi yang ada di Kalimantan Tengah Palangkaraya, maka Universitas Palangkaraya (UPR) terpanggil untuk berkontribusi dalam pencegahan dan penanganan COVID-19 yang sedang mewabah di masyarakat. Melalui Lembaga Penelitian dan Pengabdian Kepada Masyarakat (LPPM) yang ada di lingkungan UPR merumuskan kegiatan Kuliah Kerja Nyata Tematik di Masa Pandemi COVID-19 untuk percepatan penanggulangan COVID-19. Kegiatan Kuliah Kerja Nyata (KKN) Tematik merupakan kegiatan yang terjadwal secara akademik di Universitas Palanga raya Oleh karena itu, percepatan penanggulangan COVID-19 sangat srategis jika dilakukan melalui kegiatan Kuliah Kerja Nyata (KKN) Tematik. Kuliah Kerja Nyata (KKN) Tematik merupakan salah satu bentuk pengabdian kepada masyarakat yang dilakukan oleh mahasiswa secara interdisipliner, institusional, dan kemitraan sebagai salah satu wujud dari tridharma perguruan tinggi. Program pengabdian kepada masyarakat dipandang oleh Universitas Palangkaraya (UPR) sebagai program yang wajib dilaksanakan, baik oleh dosen maupun oleh mahasiswa, dengan berlandaskan pada prinsip-prinsip: (1) kompetensi akademik; (2) kewirausahaan; dan (3) professional; sehingga dapat menghasilkan program pengabdian kepada masyarakat yang bermutu, relevan, dan sinergis dalam meningkatkan pemberdayaan masyarakat Kuliah Kerja Nyata (KKN) Tematik adalah program Kuliah Kerja Nyata (KKN) Tematik dengan fokus yang spesifik dengan ciri:

(1) relevan dengan program kerja pencegahan penyebaran covid-19 di desa Tuwung kec.Pulang Pisau

(2) relevan dengan kebutuhan masyarakat

Program Kuliah Kerja Nyata (KKN) tematik ini didasarkan kepada prinsip-prinsip Pencegahaan covid-19 guna memenuhi Program kerja yang di anggarkan oleh Lembaga Penelitian dan Pengabdian Kepada Masyarakat (LPPM).

\section{METODE}

Metode penelitian kali ini menggunakan pendekatan metode kualitatif. Menurut Moleong (2005:6), penelitian kualitatif adalah penelitian yang bermaksud untuk memahami fenomena tentang apa yang dialami oleh subjek penelitian misalnya perilaku, persepsi, motivasi, tindakan, dll secara holistic, dan dengan cara deskripsi dalam bentuk kata-kata dan bahasa, pada suatu konteks khusus yang alamiah dan dengan memanfaatkan berbagai metode alamiah.

Pelaksanaannya sendiri dilakukan selama sekitar satu bulan mulai dari tanggal 07 Agustus- 07 September, dan berlokasi di desa Tuwung, Kec. Kahayan Tengah, Kab. Pulang Pisau.

Penelitian ini pengumpulan data dilakukan secara primer, dimana kelompok 49 turun langsung ke desa Tuwung melakukan observasi, dokumentasi dan wawancara.

Tahapan prosedur pelaksanaan KKN-T Periode II tahun 2020:

1. Pembekalan Mahasiswa

2. Penetapan Dosen Pembimbing

3. Pembekalan Dosen Pembimbing

4. Pengusulan dan verifikasi judul/ topik kegiatan kelompok 
5. Pembuatan jadwal kerja kelompok

6. Pembimbingan kegiatan kelompok

7. Penyampaian laporan kemajuan

8. Penulisan laporn kelompok dan naskah publikasi

9. Paparan laporan kelompok

10. Pengumpulan nilai

11. Pengumpulan laporan kelompok dan naskah publikasi

12. Pengumuman nilai dan pembagian sertifikat

\section{Alat dan Bahan}

Untuk membantu kegiatan mahasiswa dan masyarakat menghadapi fenomena covid-19, maka dibutuhkan beberapa peralatan dan bahan. Berikut adalah alat dan bahan yang kelompok kami gunakan:

Tabel 1. Alat dan bahan yang digunakan

\begin{tabular}{ll}
\hline Alat & Bahan \\
\hline Printer (1 buah) & Kertas HVS \\
\hline & Air bersih \\
\cline { 2 - 2 } Alat semprot (4 buah) & Wipol \\
\cline { 2 - 2 } & Bayclin \\
\hline Ember & Sabun, Hand sanitizer \\
\hline
\end{tabular}

\section{HASIL DAN PEMBAHASAN}

Kegiatan KKN-T kelompok 49 dengan judul "PERAN AKTIF MAHASISWA DAN MASYARAKAT DALAM MENGHADAPI FENOMENA PANDEMI COVID-19 STUDI KASUS : DESA TUWUNG, KECAMATAN KAHAYAN TENGAH" ditujukan untuk terus membiasakan masyarakat khususnya di desa Tuwung untuk menghadapi New Normal. Seperti yang kita ketahui bahwa New Normal membuat kita harus terbiasa dengan banyak hal baru, diantaranya:

1. Menghindari berjabat tangan

2. Menggunakan masker ketika keluar rumah

3. Mencuci tangan setelah bepergian

4. Meghindari kerumunan

5. Menjaga jarak minimal satu meter

6. Langsung mengganti pakaian setelah bepergian.

\section{Fakta di Lapangan}

Desa Tuwung hingga 07 september 2020 belum mencatatkan satupun kasus positif Covid-19. Hal yang patut diapresiasi mengingat penyebaran virus yang cepat dan semakin meluas tidak menginfeksi masyarakat desa Tuwung. Berikut beberapa hal yang kami temukan dalam kepatuhan masyarakat desa Tuwung dalam menjalankan protokol kesehatan yang dianjurkan Pemerintah:

Tabel 2. Kepatuhan masyarakat dalam menjalankan protokol kesehatan

Patuh Tidak Patuh




\begin{tabular}{cc}
\hline \hline & masker ketika keluar rumah \\
\hline $\begin{array}{c}\text { Disediakannya tempat mencuci tangan di tempat } \\
\text { berpotensi mengundang keramaian seperti toko- } \\
\text { toko }\end{array}$ & Mencuci tangan tidak sesuai standar WHO \\
\hline Menghindari berjabat tangan & $\begin{array}{c}\text { Kurang antisipasi dalam kebersihan publik, } \\
\text { seperti di rumah ibadah dan pertokoan }\end{array}$ \\
\hline Menghindari kerumunan & \\
\hline Mencuci tangan setelah bepergian &
\end{tabular}

Dari fakta di atas maka, kelompok 49 dibantu oleh pihak Pemerintah Desa dan masyarakat melakukan kegiatan sebagai berikut:

Tabel 2. Program yang dijalankan kelompok 49 dalam pencegahan penularan covid-19

Hari/Tanggal Deskripsi Kegiatan Keterlaksanaan Program

Terlaksana $\quad$ Tidak Terlaksana

\begin{tabular}{llll}
\hline Selasa, 11 11 & Berkoordinasi dengan tim & Ya, sesuai dengan yang \\
Agustus 2020 & $\begin{array}{l}\text { posyandu terkait kegiatan } \\
\text { posyandu yang dilakukan di } \\
\text { aula Desa Tuwung. }\end{array}$
\end{tabular}

\begin{tabular}{|c|c|c|}
\hline $\begin{array}{l}\text { Selasa, } \quad 12 \\
\text { Agustus } 2020\end{array}$ & $\begin{array}{l}\text {-Memberikan edukasi kepada } \\
\text { anak-anak desa Tuwung } \\
\text { dalam hal langkah-langkah } \\
\text { mencuci tangan yang baik } \\
\text { dan benar, agar terghindar } \\
\text { dari virus covid-19. } \\
\text {-Memberikan poster kecil } \\
\text { perihal langkah-langkah } \\
\text { mencuci tangan yang baik } \\
\text { dan benar kepada orang tua } \\
\text { yang mengikuti kegiatan } \\
\text { posyandu. }\end{array}$ & $\begin{array}{l}\text { Ya, sesuai dengan yang } \\
\text { direncanakan. }\end{array}$ \\
\hline $\begin{array}{lr}\text { Kamis, } & 13 \\
\text { Agustus } & 2020\end{array}$ & $\begin{array}{l}\text { Berkoordinasi dengan pihak } \\
\text { Berkoordinasi dengan pihak } \\
\text { kepala sekolah dan guru-guru } \\
\text { untuk ikut serta dalam proses } \\
\text { pemberian tugas dan } \\
\text { mengajar kerumah-rumah } \\
\text { anak didik kelas } 1 \text { dimasa } \\
\text { pandemi covid-19. }\end{array}$ & $\begin{array}{l}\text { Ya, sesuia dengan yang } \\
\text { direncanakan. }\end{array}$ \\
\hline $\begin{array}{l}\text { Selasa, } \quad 18 \\
\text { Agustus } 2020\end{array}$ & $\begin{array}{l}\text { Mengajar, memberikan tugas } \\
\text { dan mengedukasi siswa } \\
\text { dalam pembelajaran kelas } 1 \\
\text { SDN 2 Tuwung ditengah } \\
\text { pandemi covid }-19 \text { dan } \\
\text { Memberikan edukasi tentang } \\
\text { pencegahan Covid-19, }\end{array}$ & $\begin{array}{l}\text { Ya, sesuia dengan yang } \\
\text { direncanakan. }\end{array}$ \\
\hline
\end{tabular}




\begin{tabular}{|c|c|c|}
\hline & $\begin{array}{l}\text { seperti edukasi tentang } \\
\text { langkah-langjah mencuci } \\
\text { tangan dan etika batuk dan } \\
\text { bersin yang baik dan benar. }\end{array}$ & \\
\hline $\begin{array}{lr}\text { Rabu, } & 19 \\
\text { Agustus } & 2020\end{array}$ & $\begin{array}{l}\text { Berkoordinasi dengan } \\
\text { Kepala Desa untuk } \\
\text { meminjam alat semprot milik } \\
\text { desa untuk penyemprotan } \\
\text { Disinfektan ke tempat umum } \\
\text { dan rumah-rumah warga. }\end{array}$ & $\begin{array}{l}\text { Ya, sesuai dengan yang } \\
\text { direncanakan. }\end{array}$ \\
\hline $\begin{array}{lr}\text { Kamis, } & 20 \\
\text { Agustus } & 2020\end{array}$ & $\begin{array}{l}\text { - Penyemprotan dinsefektan } \\
\text { ketempat umum dan ke } \\
\text { rumah -rumah warga desa } \\
\text { Tuwung. }\end{array}$ & $\begin{array}{l}\text { Ya, sesuai dengan yang } \\
\text { direncanakan. }\end{array}$ \\
\hline $\begin{array}{lr}\text { Jumat, } & 21 \\
\text { Agustus } & 2020\end{array}$ & $\begin{array}{l}\text { - Pembagian masker dan } \\
\text { poster edukasi langkah- } \\
\text { langkah mencuci tangan dan } \\
\text { etika batuk dan bersin yang } \\
\text { benar. }\end{array}$ & $\begin{array}{l}\text { Ya, sesuai dengan yang } \\
\text { direncanakan. }\end{array}$ \\
\hline
\end{tabular}

Dari semua program di atas, semua dilaksanakan dengan baik berkat bantuan semua pihak. Tidak ada hambatan yang berarti dalam pelaksanaan program karena masyarakat sanagt terbuka dan menerima sosialisasi kami dengan baik dan pihak Pemerintah desa juga menyediakan alat dan bahan untuk membantu pelaksanaan berbagai kegiatan di atas.

Diharapkan dari pelaksanaan kegiatan diatas desa Tuwung tetap bebas dari kasus positif covid-19.

\section{SIMPULAN}

Kesimpulan dari Pengabdian Masyarakat ini antara lain dengan adanya sosialisasi dari mahasiswa dan pemerintah desa Tuwung, kec. Kahayan Hilir, kab. Pulang Pisau, Kalimantan Tengah dalam menghadapi fenomena pandemi covid-19, masyarakat lebih patuh untuk melaksanakan protocol kesehatan new normal life baik di lingkungan rumah dan tempat-tempat umum. Saran kepada pemerintah desa agar terus dapat membersihkan tempat-tempat umum yang berpotensi menciptakan kerumunan seperti rumah ibadah, posyandu, warung-warung dan balai desa.

\section{DAFTAR PUSTAKA}

Hidayat, Anwar, 2012, "Penelitian Kualitatif: Penjelasan Lengkap", https://www.statistikian.com/2012/10/penelitian-kualitatif.html , 15 september 2020, 21:46 